JIME (Journal of Industrial and Manufacture Engineering), 5(1) Mei 2021

ISSN 2549-6328 (Print) ISSN2549-6336 (Online) DOI : 10.31289/jime.v5i1.5054

\title{
JIME
}

(Journal of Industrial and Manufacture Engineering)

Available online http://ojs.uma.ac.id/index.php/jime

\section{Analisis Pengukuran Beban Kerja dengan Menggunakan Cardiovascular Load (CVL) pada PT. XYZ}

\section{Analysis of the Workload Measurement by Using Cardiovascular Load (CVL) and at PT. XYZ}

\author{
Sirmas Munte1), Chalis Fajri Hasibuan*2), dan Syaiful Bahri Lubis ${ }^{3)}$ \\ Program Studi Teknik Industri, Fakultas Teknik. Universitas Medan Area, Indonesia
}

Diterima: Maret 2021; Disetujui: Mei 2021; Dipublikasi: Mei 2021;

*Coresponding author: chalisfajri@yahoo.co.id

\begin{abstract}
Abstrak
PT. XYZ merupakan perusahaan industri yang bergerak dibidang pengolahan minyak kelapa sawit dan turunannya. Dengan jam kerja yang berlebih dan pola pergantian shift seminggu sekali, target produksi tidak tercapai, terjadinya kecelakaan kerja, dan adanya karyawan yang izin atau absen karena alasan sakit sehingga dapat menimbulkan beban kerja baik secara fisik maupun mental pada departemen produksi. Penelitian ini dilakukan untuk menganalisis beban kerja dengan menggunakan metode Cardiovascular Load (CVL). Hasil perhitungan metode CVL bahwa beban kerja fisik yang paling besar pada shift I dan shift II dirasakan oleh Pekerja 8 dari Stasiun Refra 3 grup C dengan nilai \% CVL sebesar 36,73 \% dan 32,38 \% dengan keterangan diperlukan perbaikan. Berdasarkan hasil CVL sebanyak 9 karyawan mengalami beban kerja fisik.
\end{abstract}

Kata kunci : Beban kerja, Cardiovascular Load (CVL)

\begin{abstract}
PT. XYZ is an industrial company engaged in the processing of palm oil and its derivatives. With excessive working hours and pattern of changing shifts once a week, production targets ar not achieved, work accidents occur, and there are employees who are absent due to illness, which can cause workload both physically and mentally in the production department. This study was conducted to analyze workload using the Cardiovascular Load (CVL). The results of the CVL method calculation show that the greatest physical workload on the shift I and shift II is felt by Worker 8 from the Refra 3 Station group C with a percentage of CVL values of $36.73 \%$ and $32.38 \%$ with information that improvements was needed.. Based on the results Cardiovascular Load (CVL) and NASA-TLX, there were 9 employees experienced physical workloads.
\end{abstract}

Key Words: Workload, Cardiovascular Load (CVL)

How to Cite: Munte, Sirmas, Chalis Fajri Hasibuan, dan Syaiful Bahri Lubis(2021). Analisis Pengukuran Beban Kerja dengan Menggunakan Cardiovascular Load (CVL) pada PT. XYZ. JIME (Journal of Industrial and Manufacture Engineering). 5(1): 65 - 71 


\section{PENDAHULUAN}

Beban kerja merupakan sesuatu yang muncul akibat adanya tuntutan tugastugas, pengaruh faktor lingkungan kerja, keterampilan, perilaku dan persepsi dari pekerja. Beban kerja ini tidak hanya bersifat fisik namun juga mental. Sehingga, beban kerja yang diterima ini harus seimbang antara kemampuan fisik dan kemampuan kognitif penerima beban tersebut. Setiap orang memiliki tingkat pembebanan yang berbeda-beda sehingga perlu diupayakan tingkat intensitas pembebanan yang optimum. Tingkat pembebanan yang terlalu tinggi akan menyebabkan terjadinya overstress sedangkan tingkat pembebanan yang terlalu rendah akan menyebabkan kejenuhan dan rasa bosan atau understress (Tarwaka, 2015).

PT. XYZ merupakan perusahaan industri yang bergerak dibidang pengolahan minyak kelapa sawit dan turunannya. Bahan baku utama yang digunakan adalah Crude Palm Oil (CPO) yang kemudian diolah pada departemen produksi. Departemen ini memiliki 3 stasiun kerja yaitu Stasiun Refra 1, Stasiun Refra 2 dan Stasiun Refra 3 dengan 30 karyawan dilantai produksi terdiri dari Asisten Supervisor, Foreman dan Operator yang dibagi menjadi 3 grup yaitu grup $A$, grup B dan grup C. Proses produksi dilakukan dengan menggunakan mesin dan tenaga kerja. pergantian shift antar grupnya dilakukan seminggu sekali yaitu dari hari Senin sampai hari Kamis dan shift weekend dari hari Jumat sampai hari Minggu. Dengan shift kerja tersebut dapat diketahui bahwa pola pergantian shift yang seminggu sekali dapat menimbulkan beban kerja. Adanya target produksi RBDPO (Refined, Bleached and Deodorized
Palm Oil) yang setiap bulannya tidak tercapai maka, karyawan pada departemen produksi mengalami tekanan yang tinggi sehingga terjadi beban kerja (Dewi dan Zukri, 2016). Untuk mencapai target produksi karyawan harus lembur dan bekerja lebih cepat lagi dari biasanya. Adanya waktu kerja yang bertambah menimbulkan gejala beban kerja pada karyawan yang disertai dengan munculnya perasaan lelah, letih, lesu dan berkurangnya kewaspadaan sehingga terjadi kecelakaan kerja. maka resiko kerja yang dialami karyawan cukup berat dengan adanya berbagai kecelakaan kerja. Beberapa faktor lain yang menyebabkan beban kerja yaitu suhu dilingkungan kerja yang panas karena adanya mesin pemanas CPO yaitu mesin Plate Heat Exchanger dan Spiral Heat Exchanger. Terdapat karyawan yang izin dikarenakan sakit. Berdasarkan wawancara dengan karyawan yang bersangkutan, faktor penyebab karyawan sakit tersebut adalah diakibatkan kelelahan kerja.

Dari latar belakang diatas peneliti ingin melakukan analisis pengukuran beban kerja pada departemen produksi PT. XYZ dengan metode Cardiovascular Load (CVL), metode pengukuran beban kerja fisik didasarkan dari perbandingan antara denyut nadi kerja dengan denyut nadi maksimum serta metode National Aeronautics and Space Administration Task Load Index (NASA-TLX), metode pengukuran beban kerja mental didasarkan dari penilaian subjektif responden yang mengalami beban kerja tersebut.

\section{METODE PENELITIAN}

Jenis penelitian yang digunakan adalah penelitian deskriptif. Penelitian ini 
dilakukan pada PT. XYZ yang bergerak dalam produksi minyak kelapa sawit dan turunannya. Penelitian ini dilakukan di Departemen Produksi pada shift 1 pukul 07.00 Wib - 15.00 Wib dan shift 2 pukul 15.00 Wib - 23.00 Wib. Pertama, peneliti melakukan pengamatan dan pengukuran denyut nadi secara langsung terhadap pekerja yang berada di Stasiun Refra 1, Stasiun Refra 2 dan Stasiun Refra 3 departemen produksi. Kemudian peneliti akan mengukur denyut nadi dengan menggunakan alat yaitu Oximeter. Waktu pengambilan data denyut nadi sebanyak 4 kali untuk setiap shift yaitu pada saat sebelum bekerja, saat bekerja, saat istirahat dan saat bekerja setelah istirahat. Setelah itu hasil denyut nadi tersebut dicatat pada buku tulis.

Pengukuran denyut nadi dengan metode Cardiovascular Load (CVL) yaitu menghitung nilai \% Cardiovascular Load (CVL) dengan rumus sebagai berikut (Tarwaka, 2004)

$\% \mathrm{CVL}=$

$100 \times$ (Denyut Nadi Kerja-Denyut Nadi Istirahat)

Denyut Nadi Maksimum-Denyut Nadi Istirahat

Dimana denyut nadi istirahat adalah rerata denyut nadi sebelum pekerjaan dimulai, denyut nadi kerja adalah rerata denyut nadi selama bekerja dan denyut nadi maksimum adalah (220 - umur) untuk laki-laki dan (200 - umur) untuk wanita. Dari hasil perhitungan \% CVL tersebut kemudian dibandingkan dengan klasifikasi yang telah ditetapkan sebagai berikut (Dewi Diniaty, 2016) :

1. $<30 \%=$ Tidak terjadi kelelahan

2. $30-<60 \%=$ Diperlukan perbaikan

3. $60-<80=$ Kerja dalam waktu singkat

4. $80-<100 \%=$ Diperlukan tindakan segera
5. $100 \%=$ Tidak diperbolehkan
beraktivitas

\section{HASIL DAN PEMBAHASAN}

Dalam penelitian ini data yang dikumpulkan yaitu hasil pengukuran denyut nadi karyawan dan hasil penyebaran kuesioner NASA-TLX terhadap 30 orang karyawan seperti pada tabel 1 berikut

Tabel 1. Data Pekerja Departemen Produksi

\begin{tabular}{|c|c|c|c|c|c|c|}
\hline Grup & Stasiun & Nama & $\begin{array}{l}\text { Jenis } \\
\text { Kerja }\end{array}$ & $\begin{array}{l}\text { Jenis } \\
\text { Kelamin }\end{array}$ & $\begin{array}{l}\text { Umur } \\
\text { tahun) }\end{array}$ & $\begin{array}{c}\text { Lama } \\
\text { Kerja } \\
\text { (Tahun) }\end{array}$ \\
\hline \multirow[t]{10}{*}{ A } & $\begin{array}{l}\text { Refra } 1 \\
\text { dan } 2\end{array}$ & Pekerja 1 & $\begin{array}{l}\text { Asisten } \\
\text { Suprvisr }\end{array}$ & Laki-laki & 42 & 21 \\
\hline & Refra 1 & Pekerja 2 & Foreman & Laki-laki & 45 & 20 \\
\hline & Refra 1 & Pekerja 3 & Operator & Laki-laki & 41 & 18 \\
\hline & Refra 2 & Pekerja 4 & Foreman & Laki-laki & 41 & 24 \\
\hline & Refra 2 & Pekerja 5 & Operator & Laki-laki & 41 & 19 \\
\hline & Refra 2 & Pekerja 6 & Operator & Laki-laki & 35 & 8 \\
\hline & Refra 2 & Pekerja 7 & Operator & Laki-laki & 42 & 20 \\
\hline & Refra 3 & Pekerja 8 & $\begin{array}{l}\text { Asisten } \\
\text { Suprvisr }\end{array}$ & Laki-laki & 40 & 20 \\
\hline & Refra 3 & Pekerja 9 & Operator & Laki-laki & 41 & 19 \\
\hline & Refra 3 & Pekerja 10 & Operator & Laki-laki & 40 & 19 \\
\hline \multirow[t]{10}{*}{ B } & $\begin{array}{l}\text { Refra } 1 \\
\text { dan } 2\end{array}$ & Pekerja 1 & $\begin{array}{l}\text { Asisten } \\
\text { Supervisor }\end{array}$ & Laki-laki & 43 & 21 \\
\hline & Refra 1 & Pekerja 2 & Foreman & Laki-laki & 40 & 20 \\
\hline & Refra 1 & Pekerja 3 & Operator & Laki-laki & 43 & 20 \\
\hline & Refra 2 & Pekerja 4 & Operator & Laki-laki & 29 & 7 \\
\hline & Refra 2 & Pekerja 5 & Operator & Laki-laki & 40 & 20 \\
\hline & Refra 2 & Pekerja 6 & Operator & Laki-laki & 41 & 20 \\
\hline & Refra 2 & Pekerja 7 & Foreman & Laki-laki & 41 & 20 \\
\hline & Refra 3 & Pekerja 8 & $\begin{array}{l}\text { Asisten } \\
\text { Supervisor }\end{array}$ & Laki-laki & 40 & 19 \\
\hline & Refra 3 & Pekerja 9 & Foreman & Laki-laki & 43 & 20 \\
\hline & Refra 3 & Pekerja 10 & Operator & Laki-laki & 30 & 6 \\
\hline \multirow[t]{10}{*}{$\mathrm{C}$} & $\begin{array}{l}\text { Refra } 1 \\
\text { dan } 2\end{array}$ & Pekerja 1 & $\begin{array}{l}\text { Asisten } \\
\text { Supervisor }\end{array}$ & Laki-laki & 40 & 19 \\
\hline & Refra 1 & Pekerja 2 & Operator & Laki-laki & 39 & 18 \\
\hline & Refra 1 & Pekerja 3 & Foreman & Laki-laki & 43 & 20 \\
\hline & Refra 2 & Pekerja 4 & Operator & Laki-laki & 40 & 18 \\
\hline & Refra 2 & Pekerja 5 & Foreman & Laki-laki & 40 & 19 \\
\hline & Refra 2 & Pekerja 6 & Operator & Laki-laki & 31 & 7 \\
\hline & Refra 2 & Pekerja 7. & Operator & Laki-laki & 46 & 22 \\
\hline & Refra 3 & Pekerja 8 & $\begin{array}{l}\text { Asisten } \\
\text { Supervisor }\end{array}$ & Laki-laki & 46 & 23 \\
\hline & Refra 3 & Pekerja 9 & Foreman & Laki-laki & 42 & 21 \\
\hline & Refra 3 & Pekerja 10 & Operator & Laki-laki & 34 & 7 \\
\hline
\end{tabular}

Setelah melihat tabel 1 diatas dilakukan pengambilan data denyut nadi diperoleh dengan menggunnakan alat oximeter. Adapun waktu pengambilan data denyut nadi kerja pada shift 1 dan 2 dalam selang waktu dapat dilihat pada tabel 2 berikut. 
Sirmas Munte, Chalis Fajri Hasibuan, dan Syaiful Bahri Lubis. Analisis Pengukuran Beban Kerja dengan Menggunakan Cardiovascular Load (CVL) pada PT. XYZ

Tabel 2. Waktu Pengukuran Denyut Nadi Kerja Pekerja

\begin{tabular}{ccc}
\hline $\begin{array}{c}\text { Pengukuran } \\
\text { Ke- }\end{array}$ & $\begin{array}{c}\text { Waktu } \\
\text { Pengukuran Shift I }\end{array}$ & $\begin{array}{c}\text { Waktu } \\
\text { Pengukuran } \\
\text { Shift II }\end{array}$ \\
\hline 1 & $09: 00-09: 30$ & $17: 00-17: 30$ \\
2 & $13: 00-13: 30$ & $21: 00-21: 30$ \\
\hline
\end{tabular}

Adapun waktu pengambilan data denyut nadi istirahat pada shift 1 dan 2 dalam selang waktu dapat dilihat pada tabel 3 berikut.

Tabel 3. Waktu Pengukuran Denyut Nadi Istirahat Pekerja

\begin{tabular}{ccc}
\hline $\begin{array}{c}\text { Pengukuran } \\
\text { Ke- }\end{array}$ & $\begin{array}{c}\text { Waktu } \\
\text { Pengukuran Shift I }\end{array}$ & $\begin{array}{c}\text { Waktu } \\
\text { Pengukuran } \\
\text { Shift II }\end{array}$ \\
\hline 1 & $06: 30-07: 00$ & $14: 30-15: 00$ \\
2 & $12: 00-12: 30$ & $20: 00-20: 30$ \\
\hline
\end{tabular}

Hasil rekapitulasi dari perhitungan Cardiovascular Load (CVL) pada masingmasing grup untuk shift 1 dapat dilihat pada tabel 4 berikut.

Tabel 4. Rekapitulasi Pengolahan Data Menggunakan Cardiovascular Load (CVL) Shift I

\begin{tabular}{|c|c|c|c|c|c|c|c|}
\hline $\begin{array}{l}\text { Gru Jami } \\
\mathrm{p}\end{array}$ & Umur & \multirow{2}{*}{$\begin{array}{c}\text { DNK } \\
93\end{array}$} & $\begin{array}{c}\text { DNK } \\
\text { Rata- } \\
\text { rata }\end{array}$ & DNI & $\begin{array}{r}\text { DNI } \\
\text { I Rata- } \\
\text { rata }\end{array}$ & $\begin{array}{cc}\mathrm{DN} & \% \\
\max & \mathrm{CVL}\end{array}$ & Ket \\
\hline \multirow[t]{20}{*}{$\mathrm{A}$} & \multirow{2}{*}{ Pekerja 142} & & 97,5 & 68 & 70,5 & 17825,11 & Tidak \\
\hline & & 102 & & 73 & & & $\begin{array}{c}\text { Terjadi } \\
\text { kelelahan }\end{array}$ \\
\hline & \multirow[t]{2}{*}{ Pekerja 245} & 95 & 99,5 & 70 & 72 & 17526,69 & Tidak \\
\hline & & 104 & & 74 & & & $\begin{array}{c}\text { terjadi } \\
\text { kelelahan }\end{array}$ \\
\hline & \multirow[t]{2}{*}{ Pekerja 341} & 88 & 92 & 69 & 71,5 & 17919,06 & Tidak \\
\hline & & 96 & & 74 & & & $\begin{array}{c}\text { Terjadi } \\
\text { kelelahan }\end{array}$ \\
\hline & \multirow[t]{2}{*}{ Pekerja 441} & 93 & 96 & 67 & 71 & 17923,12 & Tidak \\
\hline & & 99 & & 75 & & & $\begin{array}{c}\text { terjadi } \\
\text { kelelahan }\end{array}$ \\
\hline & \multirow[t]{2}{*}{ Pekerja 541} & 86 & 90,5 & 71 & 73,5 & 17916,11 & Tidak \\
\hline & & 95 & & 76 & & & $\begin{array}{c}\text { Terjadi } \\
\text { kelelahan }\end{array}$ \\
\hline & \multirow[t]{2}{*}{ Pekerja 635} & 85 & 88 & 68 & 70,5 & 18515,28 & Tidak \\
\hline & & 91 & & 73 & & & $\begin{array}{c}\text { terjadi } \\
\text { kelelahan }\end{array}$ \\
\hline & \multirow[t]{2}{*}{ Pekerja 742} & 93 & 96,5 & 67 & 71 & 17823,83 & Tidak \\
\hline & & 100 & & 75 & & & $\begin{array}{c}\text { Terjadi } \\
\text { kelelahan }\end{array}$ \\
\hline & \multirow[t]{2}{*}{ Pekerja 840} & 87 & 90,5 & 69 & 73 & 18016,35 & Tidak \\
\hline & & 94 & & 77 & & & $\begin{array}{c}\text { terjadi } \\
\text { kelelahan }\end{array}$ \\
\hline & \multirow[t]{2}{*}{ Pekerja 941} & 93 & 95,5 & 68 & 70,5 & 17923,04 & Tidak \\
\hline & & 98 & & 73 & & & $\begin{array}{c}\text { Terjadi } \\
\text { kelelahan }\end{array}$ \\
\hline & \multirow[t]{2}{*}{ Pekerja 1040} & 92 & 94,5 & 70 & 72 & 18020,83 & Tidak \\
\hline & & 97 & & 74 & & & $\begin{array}{c}\text { terjadi } \\
\text { kelelahan }\end{array}$ \\
\hline \multirow[t]{2}{*}{ B } & \multirow[t]{2}{*}{ Pekerja 143} & 86 & 90 & 71 & 73 & 17716,34 & Tidak \\
\hline & & 94 & & 75 & & & Terjadi \\
\hline
\end{tabular}

\begin{tabular}{|c|c|c|c|c|c|c|c|}
\hline & u Jami Umur & DNK & $\begin{array}{l}\text { DNK } \\
\text { Rata- } \\
\text { rata } \\
\end{array}$ & DNI & $\begin{array}{c}\text { DNI } \\
\text { Rata- } \\
\text { rata } \\
\end{array}$ & $\begin{array}{lc}\mathrm{DN} & \% \\
\max & \mathrm{CVL}\end{array}$ & Ket \\
\hline \multirow{3}{*}{\multicolumn{2}{|c|}{ Pekerja 240}} & & & & & & kelelahan \\
\hline & & 100 & 102 & 69 & 71,5 & 18028,11 & Tidak \\
\hline & & 104 & & 74 & & & $\begin{array}{c}\text { terjadi } \\
\text { kelelahan }\end{array}$ \\
\hline \multirow{2}{*}{\multicolumn{2}{|c|}{ Pekerja 343}} & 101 & 102 & 77 & 79 & 17727,55 & Tidak \\
\hline & & 103 & & 81 & & & $\begin{array}{c}\text { Terjadi } \\
\text { kelelahan }\end{array}$ \\
\hline \multirow{2}{*}{\multicolumn{2}{|c|}{ Pekerja 429}} & 90 & 94,5 & 73 & 75 & 19116,81 & Tidak \\
\hline & & 99 & & 77 & & & $\begin{array}{c}\text { terjadi } \\
\text { kelelahan }\end{array}$ \\
\hline \multirow{2}{*}{\multicolumn{2}{|c|}{ Pekerja 540}} & 89 & 92 & 71 & 73,5 & 18017,37 & Tidak \\
\hline & & 95 & & 76 & & & $\begin{array}{c}\text { Terjadi } \\
\text { kelelahan }\end{array}$ \\
\hline \multirow{2}{*}{\multicolumn{2}{|c|}{ Pekerja 641}} & 97 & 98,5 & 70 & 72 & 17924,53 & Tidak \\
\hline & & 100 & & 74 & & & $\begin{array}{c}\text { terjadi } \\
\text { kelelahan }\end{array}$ \\
\hline \multirow{2}{*}{\multicolumn{2}{|c|}{ Pekerja 741}} & 102 & 104 & 69 & 71 & 17930,55 & Tidak \\
\hline & & 106 & & 73 & & & $\begin{array}{c}\text { Terjadi } \\
\text { kelelahan }\end{array}$ \\
\hline \multirow{2}{*}{\multicolumn{2}{|c|}{ Pekerja 840}} & 100 & 104,5 & 74 & 76,5 & 18026,08 & Tidak \\
\hline & & 109 & & 79 & & & $\begin{array}{c}\text { terjadi } \\
\text { kelelahan }\end{array}$ \\
\hline \multirow{2}{*}{\multicolumn{2}{|c|}{ Pekerja 943}} & 100 & 103 & 78 & 80 & 17723,71 & Tidak \\
\hline & & 106 & & 82 & & & $\begin{array}{c}\text { Terjadi } \\
\text { kelelahan }\end{array}$ \\
\hline \multirow{2}{*}{\multicolumn{2}{|c|}{ Pekerja 1030}} & 93 & 96 & 72 & 75 & 19018,26 & Tidak \\
\hline & & 99 & & 78 & & & terjadi \\
\hline \multirow[t]{22}{*}{$\mathrm{C}$} & \multirow{3}{*}{ Pekerja 140} & 103 & 106 & 73 & 76 & 18028.84 & Tidak \\
\hline & & 109 & & 79 & & & Terjadi \\
\hline & & & & & & & kelelahan \\
\hline & \multirow[t]{2}{*}{ Pekerja 239} & 100 & 105 & 71 & 73,5 & 18129,30 & Tidak \\
\hline & & 110 & & 76 & & & $\begin{array}{c}\text { terjadi } \\
\text { kelelahan }\end{array}$ \\
\hline & \multirow[t]{2}{*}{ Pekerja 343} & 101 & 105 & 70 & 72 & 17731,42 & Tidak \\
\hline & & 109 & & 74 & & & $\begin{array}{c}\text { Terjadi } \\
\text { kelelahan }\end{array}$ \\
\hline & \multirow{2}{*}{ Pekerja 440} & 105 & 107,5 & 71 & 72,5 & 18032,55 & Tidak \\
\hline & & 110 & & 74 & & & $\begin{array}{c}\text { terjadi } \\
\text { kelelahan }\end{array}$ \\
\hline & \multirow[t]{2}{*}{ Pekerja 540} & 96 & 97,5 & 69 & 71 & 18024,31 & Tidak \\
\hline & & 99 & & 73 & & & $\begin{array}{c}\text { Terjadi } \\
\text { kelelahan }\end{array}$ \\
\hline & \multirow[t]{2}{*}{ Pekerja 631} & 98 & 100 & 68 & 70 & 18925,21 & Tidak \\
\hline & & 102 & & 72 & & & $\begin{array}{c}\text { terjadi } \\
\text { kelelahan }\end{array}$ \\
\hline & \multirow[t]{2}{*}{ Pekerja 746} & 93 & 94,5 & 72 & 74,5 & 17420,10 & Tidak \\
\hline & & 96 & & 77 & & & $\begin{array}{c}\text { Terjadi } \\
\text { kelelahan }\end{array}$ \\
\hline & \multirow{2}{*}{ Pekerja 846} & 109 & 112 & 73 & 76 & 17436,73 & Tidak \\
\hline & & 115 & & 79 & & & $\begin{array}{c}\text { terjadi } \\
\text { kelelahan }\end{array}$ \\
\hline & \multirow[t]{2}{*}{ Pekerja 942} & 106 & 109,5 & 71 & 73,5 & 17834,44 & Tidak \\
\hline & & 113 & & 76 & & & $\begin{array}{c}\text { Terjadi } \\
\text { kelelahan }\end{array}$ \\
\hline & \multirow[t]{3}{*}{ Pekerja 1034} & 100 & 104,5 & 71 & 72,5 & 18628,19 & Tidak \\
\hline & & 109 & & 7 & & & terjadi \\
\hline & & & & 4 & & & kelelahan \\
\hline
\end{tabular}

Hasil rekapitulasi dari perhitungan Cardiovascular Load (CVL) pada masingmasing grup untuk shift 2 adalah dapat dilihat pada tabel 5 berikut. 
Tabel 5. Rekapitulasi Pengolahan Data Menggunakan Cardiovascular Load (CVL) Shift II

\begin{tabular}{|c|c|c|c|c|c|c|c|c|}
\hline Grup & Nama & Jmu: & DNK & $\begin{array}{c}\text { DNK } \\
\text { Rata- } \\
\text { rata }\end{array}$ & DNI & $\begin{array}{l}\text { DNI } \\
\text { Rata- } \\
\text { rata }\end{array}$ & $\begin{array}{cc}\mathrm{DN} & \% \\
\max & \mathrm{CVL}\end{array}$ & Ket \\
\hline \multirow[t]{20}{*}{ A } & Pekerja 1 & 42 & 99 & 103,5 & 77 & 79 & 17824,74 & Tidak \\
\hline & & & 108 & & 81 & & & $\begin{array}{c}\text { Terjadi } \\
\text { kelelahan }\end{array}$ \\
\hline & Pekerja 2 & 45 & 100 & 103,5 & 80 & 81,5 & 17523,52 & Tidak \\
\hline & & & 107 & & 83 & & & $\begin{array}{c}\text { terjadi } \\
\text { kelelahan }\end{array}$ \\
\hline & Pekerja 3 & 41 & 101 & 104,5 & 78 & 79,5 & 17925,12 & Tidak \\
\hline & & & 108 & & 81 & & & $\begin{array}{c}\text { Terjadi } \\
\text { kelelahan }\end{array}$ \\
\hline & Pekerja 4 & 41 & 95 & 98,5 & 77 & 80 & 17918,68 & Tidak \\
\hline & & & 102 & & 83 & & & $\begin{array}{c}\text { terjadi } \\
\text { kelelahan }\end{array}$ \\
\hline & Pekerja 5 & 41 & 94 & 100 & 80 & 82 & 17918,55 & Tidak \\
\hline & & & 106 & & 84 & & & $\begin{array}{c}\text { Terjadi } \\
\text { kelelahan }\end{array}$ \\
\hline & Pekerja 6 & 35 & 98 & 100 & 79 & 81,5 & 18517,87 & Tidak \\
\hline & & & 102 & & 84 & & & $\begin{array}{c}\text { terjadi } \\
\text { kelelahan }\end{array}$ \\
\hline & Pekerja 7 & 42 & 97 & 100 & 81 & 83 & 17817,89 & Tidak \\
\hline & & & 103 & & 85 & & & $\begin{array}{c}\text { Terjadi } \\
\text { kelelahan }\end{array}$ \\
\hline & Pekerja 8 & 40 & 104 & 107 & 82 & 83,5 & 18024,35 & Tidak \\
\hline & & & 110 & & 85 & & & $\begin{array}{c}\text { terjadi } \\
\text { kelelahan }\end{array}$ \\
\hline & Pekerja 9 & 41 & 97 & 103 & 80 & 83 & 17920,83 & Tidak \\
\hline & & & 109 & & 86 & & & $\begin{array}{c}\text { Terjadi } \\
\text { kelelahan }\end{array}$ \\
\hline & Pekerja 10 & 040 & 100 & 104 & 79 & 81 & 18023,23 & Tidak \\
\hline & & & 108 & & 83 & & & $\begin{array}{c}\text { terjadi } \\
\text { kelelahan }\end{array}$ \\
\hline \multirow[t]{6}{*}{ B } & Pekerja 1 & 43 & 99 & 103 & 84 & 85,5 & 17719,12 & Tidak \\
\hline & & & 107 & & 87 & & & $\begin{array}{c}\text { Terjadi } \\
\text { kelelahan }\end{array}$ \\
\hline & Pekerja 2 & 40 & 106 & 108 & 81 & 83,5 & 18025,38 & Tidak \\
\hline & & & 110 & & 86 & & & $\begin{array}{c}\text { terjadi } \\
\text { kelelahan }\end{array}$ \\
\hline & Pekerja 3 & 43 & 105 & 108,5 & 80 & 82,5 & 17727,51 & Tidak \\
\hline & & & 112 & & 85 & & & $\begin{array}{c}\text { Terjadi } \\
\text { kelelahan }\end{array}$ \\
\hline
\end{tabular}

Pekerja 429108 110,5 79 81,5 19126,48 Tidak $11384 \quad$ terjadi

Pekerja $5 \quad 40 \quad 106 \quad 110,581 \quad 84 \quad 18027,60 \quad \begin{gathered}\text { kelelahan } \\ \text { Tidak }\end{gathered}$ $115 \quad 87 \quad$ Terjadi kelelahan

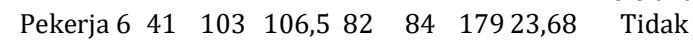
$110 \quad 86 \quad$ terjadi kelelahan

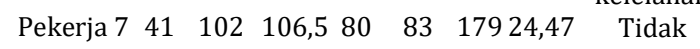
$11186 \quad$ Terjadi kelelahan

\begin{tabular}{|c|c|c|c|c|c|c|}
\hline \multirow[b]{2}{*}{ Pekerja 840} & & & & & & \multirow[b]{2}{*}{$\begin{array}{c}\text { Tidak } \\
\text { terjadi } \\
\text { kelelahan }\end{array}$} \\
\hline & $\begin{array}{l}103 \\
112\end{array}$ & 107,5 & $\begin{array}{l}83 \\
87\end{array}$ & 85 & $180 \overline{23,68}$ & \\
\hline Pekerja 943 & $\begin{array}{l}100 \\
109\end{array}$ & 104,5 & $\begin{array}{l}80 \\
84\end{array}$ & 82 & 17723,68 & $\begin{array}{c}\text { Tidak } \\
\text { Terjadi } \\
\text { kelelahan }\end{array}$ \\
\hline Pekerja 1030 & $\begin{array}{l}101 \\
109\end{array}$ & 105 & $\begin{array}{l}81 \\
86\end{array}$ & 83,5 & 19020,18 & $\begin{array}{c}\text { Tidak } \\
\text { terjadi } \\
\text { kelelahan }\end{array}$ \\
\hline Pekerja 140 & $\begin{array}{l}107 \\
115\end{array}$ & 111 & $\begin{array}{l}80 \\
84\end{array}$ & 82 & 18029,59 & $\begin{array}{c}\text { Tidak } \\
\text { Terjadi } \\
\text { kelelahan }\end{array}$ \\
\hline Pekerja 239 & $\begin{array}{l}117 \\
121\end{array}$ & 119 & $\begin{array}{l}89 \\
91\end{array}$ & 90 & 18131,86 & $\begin{array}{c}\text { Tidak } \\
\text { terjadi } \\
\text { kelelahan }\end{array}$ \\
\hline
\end{tabular}

Pekerja $3 \quad 43 \quad 110 \quad 113 \quad 83 \quad 85 \quad 17730,43 \quad$ Tidak $\begin{array}{lllll}116 & 87 & & \text { Terjadi }\end{array}$

\begin{tabular}{|c|c|c|c|c|c|c|c|c|}
\hline Grup & Nama & Jmu & DNK & $\begin{array}{c}\text { DNK } \\
\text { Rata- } \\
\text { rata }\end{array}$ & DNI & $\begin{array}{l}\text { DNI } \\
\text { Rata- } \\
\text { rata }\end{array}$ & $\begin{array}{l}\mathrm{DN} \quad \% \\
\max \quad \mathrm{CVL}\end{array}$ & Ket \\
\hline \multirow{3}{*}{\multicolumn{2}{|c|}{ Pekerja 4}} & & & & & & & kelelahan \\
\hline & & 40 & 110 & 112,5 & 80 & 83 & 18030,41 & Tidak \\
\hline & & & 115 & & 86 & & & $\begin{array}{c}\text { terjadi } \\
\text { kelelahan }\end{array}$ \\
\hline \multirow{2}{*}{\multicolumn{2}{|c|}{ Pekerja 5}} & 40 & 100 & 105 & 83 & 85 & 18021,05 & Tidak \\
\hline & & & 110 & & 87 & & & $\begin{array}{c}\text { Terjadi } \\
\text { kelelahan }\end{array}$ \\
\hline \multirow{2}{*}{\multicolumn{2}{|c|}{ Pekerja 6}} & 31 & 109 & 111,5 & 80 & 82 & 18927,57 & Tidak \\
\hline & & & 114 & & 84 & & & $\begin{array}{c}\text { terjadi } \\
\text { kelelahan }\end{array}$ \\
\hline \multirow{2}{*}{\multicolumn{2}{|c|}{ Pekerja 7}} & 46 & 104 & 107 & 81 & 83,5 & 17425,96 & Tidak \\
\hline & & & 110 & & 86 & & & $\begin{array}{c}\text { Terjadi } \\
\text { kelelahan }\end{array}$ \\
\hline \multirow{2}{*}{\multicolumn{2}{|c|}{ Pekerja 8}} & 46 & 111 & 114,5 & 83 & 86 & 17432,38 & Tidak \\
\hline & & & 118 & & 89 & & & $\begin{array}{c}\text { terjadi } \\
\text { kelelahan }\end{array}$ \\
\hline \multirow{2}{*}{\multicolumn{2}{|c|}{ Pekerja 9}} & 42 & 105 & 110,5 & 81 & 83 & 17828,94 & Tidak \\
\hline & & & 116 & & 85 & & & $\begin{array}{c}\text { Terjadi } \\
\text { kelelahan }\end{array}$ \\
\hline \multirow{2}{*}{\multicolumn{3}{|c|}{ Pekerja 1034}} & 108 & 112 & 79 & 82 & 18628,84 & Tidak \\
\hline & & & 116 & & 85 & & & $\begin{array}{c}\text { terjadi } \\
\text { kelelahan }\end{array}$ \\
\hline
\end{tabular}

Berdasarkan tabel 4. Dan tabel 5. diatas bahwa \% CVL dengan kategori diperlukan perbaikan banyak terdapat pada grup C Stasiun Refra 1 dan Refra 2, hal ini dikarenakan usia pekerja digrup $C$ rata-rata 40 tahun serta pada Stasiun Refra 1 dan Refra 2, dimana kedua stasiun ini menggunakan mesin yang tidak sama baik dengan Stasiun Refra 3 sehingga aktivitas karyawan pada Stasiun Refra 1 dan 2 lebih produktif dikarenakan sering naik turun akibat mesin yang bermasalah tersebut. Hal ini dapat menyebabkan kelelahan fisik pada pekerja.

Berdasarkan hasil yang diperoleh dari perhitungan denyut nadi dapat diketahui bahwa sebanyak 1 karyawan grup B mengalami beban kerja kerja fisik kategori diperlukan perbaikan dan 9 orang mengalami beban kerja fisik kategori tidak terjadi kelelahan saat shift 1 . Kemudian seluruh karyawan grup B mengalami beban kerja fisik kategori tidak terjadi kelelahan saat shift 2, untuk karyawan grup C mengalami beban kerja fisik kategori diperlukan perbaikan dan 6 
karyawan mengalami beban kerja fisik kategori tidak terjadi kelelahan saat shift 1

Kemudian sebanyak 4 karyawan grup B mengalami beban kerja fisik kategori diperlukan perbaikan dan 6 karyawan mengalami beban kerja fisik kategori tidak terjadi kelelahan saat shift 2 . Dalam hal ini, secara keseluruhan banyaknya beban kerja fisik dalam kategori diperlukan perbaikan untuk masing-masing grup dan shift dapat dilihat pada tabel 6 berikut.

Tabel 6. Jumlah Beban Kerja Karyawan Kategori Diperlukan Perbaikan Dan Sangat Tinggi

\begin{tabular}{|c|c|c|}
\hline Beban Kerja & \multicolumn{2}{|c|}{ Beban Kerja Fisik } \\
\hline & Shift I & Shift II \\
\hline & 5 karyawan & 4 karyawan \\
\hline Jumlah & \multicolumn{2}{|c|}{9 karyawan } \\
\hline
\end{tabular}

Berdasarkan tabel 6 diatas dapat diketahui bahwa sebanyak 5 karyawan mengalami beban kerja fisik dalam kategori diperlukan perbaikan saat shift 1 dan 4 karyawan mengalami beban kerja fisik dalam kategori diperlukan perbaikan saat shift 2, sehingga terdapat 9 karyawan mengalami beban kerja fisik dan 5 karyawan mengalami beban kerja mental pada PT. XYZ.

Kemudian dilakukan analisis pertama yaitu analisis berdasarkan hasil perhitungan beban kerja fisik menggunakan persentase CVL menunjukkan bahwa karyawan di depatemen produksi PT. XYZ yang memiliki beban kerja fisik tinggi untuk shift I dan shift II diterima oleh karyawan di stasiun Refra 3 grup C yaitu Pekerja 8 dengan \%CVL sebesar 36,73\% dan 32,38 $\%$. Dari klasifikasi persentase CVL yang diperlukan perbaikan terdapat sembilan karyawan dengan shift I sebanyak lima orang karyawan dan shift II sebanyak empat orang karyawan. Hal ini secara keseluruhan dikarenakan sistem shift kerja yang kurang baik yaitu pergantian shift dilakukan per seminggu sekali yang hanya tiga grup apalagi tenaga kerja yang bekerja pada shift 2 mengalami peningkatan kelelahan kerja (Lusi, 2015), Aktivitas kerja sebagai foreman yang terkadang rangkap sebagai operator, Perusahaan tidak menyediakan minum bagi karyawan departemen produksi, Factor usia juga mempengaruhi beban kerja yang rata-rata usia karyawan diatas 40 tahun (Birthda,2018), dan suhu udara yang panas dikarenakan letak PT. XYZ bersebelahan langsung dengan laut juga dapat menyebabkan karyawan mudah merasa lelah.

Pada akhirnya setelah analisis Cardiovascular Load (CVL) dan NASA-TLX, maka dilakukan analisis perbandingan berdasarkan hasil perhitungan beban kerja fisik menggunakan persentase CVL terdapat 9 orang karyawan mengalami beban kerja fisik. Namun, tidak ada karyawan perusahaan PT.XYZ yang memiliki beban kerja fisik dan beban kerja mental yang keduanya sama tinggi melainkan hanya memiliki beban kerja pada fisik dan beban kerja mental saja. Dalam hal ini dikarenakan faktor penyebab terjadinya beban kerja yang dialami karyawan yang berbeda-beda seperti yang dijelaskan dalam Tarwaka, 2004 yaitu tingkat emosi pekerja yang berbeda, ukuran tubuh pekerja yang berbeda, status gizi pekerja yang berbeda, motivasi pekerja yang berbeda dan kepercayaan pekerja yang berbeda.

\section{KESIMPULAN}

Berdasarkan hasil perhitungan dengan menggunakan metode Cardiovascular Load (CVL) diperoleh 
bahwa beban kerja fisik yang paling besar pada shift I dan shift II dirasakan oleh Kaliper Pasaribu dari stasiun refra 3 grup C dengan nilai \% CVL sebesar 36,73\% dan $32,38 \%$ dengan keterangan diperlukan perbaikan. Kemudian pada shift II Pekerja 1 dari Stasiun Refra 1 dan Refra 2 grub C sebesar 81,33\% dan Pekerja 2 dari Stasiun Refra 3 grup C sebesar 85,33\%. Sehingga sebanyak 5 orang karyawan mengalami beban kerja fisik dalam kategori diperlukan perbaikan saat shift 1 dan 4 orang karyawan mengalami beban kerja fisik dalam kategori diperlukan perbaikan saat shift 2 pada PT. XYZ.

\section{DAFTAR PUSTAKA}

Birthda Amini Deyulmar, Suroto dan Ida Wahyuni.2018.Analisis Faktor-faktor yang Berhubungan Dengan Kelelahan Kerja Pada
Pekerja Pembuat Kerupuk Opak Di Desa Ngadikerso, Kabupaten Semarang.Jurnal Kesehatan Masyarakat, 6(4), 2356-3346.

Dewi Diniaty dan Zukri Muliadi. 2016.Analisis Beban Kerja Fisik dan Mental Karyawan Pada Lantai Produksi Di PT. PesonaLaut Kuning. Jurnal Sains, Teknologi dan Industri, 13(2), 203-210.

Lusi Fatona.2015.Perbedaan Tingkat Kelelahan Antara Shift Pagi, Sore dan Malam Pada Perawat Rawat Inap Di RS PKU Aisyiyah Boyolali.Program Studi Kesehatan Masyarakat, Universitas Muhammadiyah Surakarta.

Tarwaka, dkk.2015. Ergonomi Industri: Dasar dasar Pengetahuan Ergonomi dan Aplikasi di Tempat Kerja Revisi Edisi II, Surakarta: Harapan Press.

Tarwaka, Solichul,H., Bakri, A., \&Sudiajeng, L. 2004. Ergonomi untuk Kesehatan dan Keselamatan Kerja dan Produktivitas. Surakarta: UNIBA Press. 